VOLUME XXVII - NUMBER $4 \cdot$ December 1968
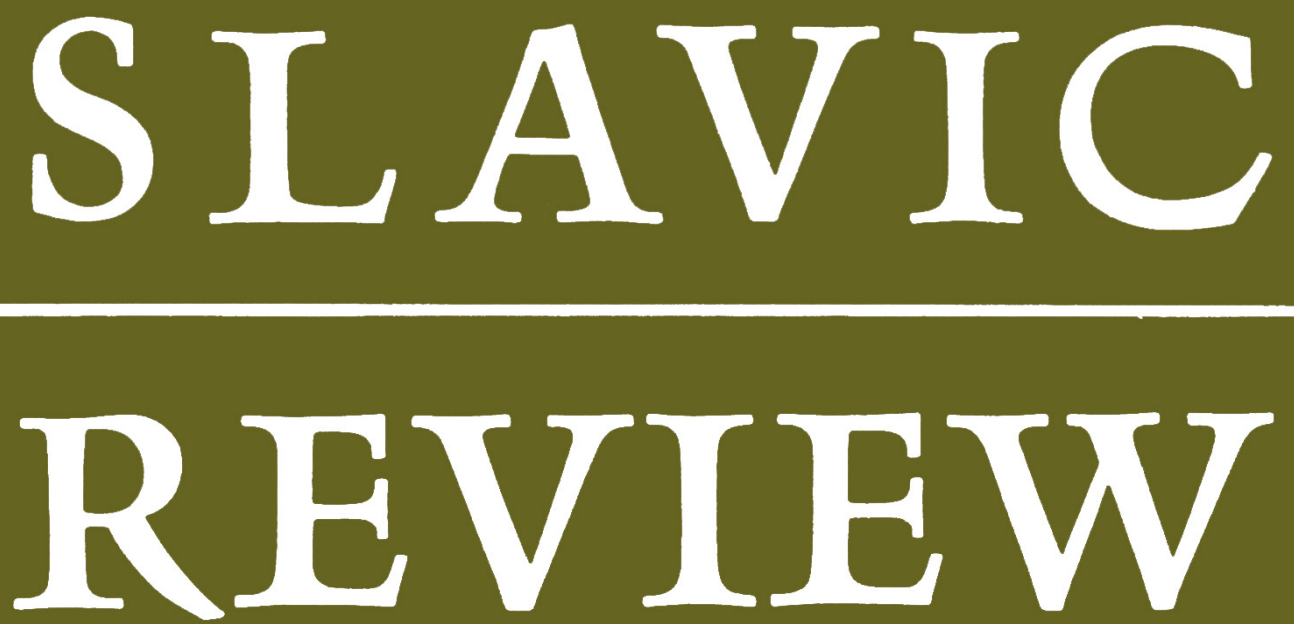

American Quarterly of Soviet and East European Studies 


\section{HONORARY EDITORS}

Harold H. Fisher Oscar Halegci Geroid T. Robinson Ernest J. Simmons S. Harrison Thomson George Vernadsky

\section{EDITORIAL ADVISORY COMMTTTEE}

Frederick G. Barghoorn, Yale University - Abram Bergson, Harvard University - Cyril E. Black, Princeton University - Deming Brown, University of Michigan - Robert F. Byrnes, Indiana University - John S. Curtiss, Duke University - William B. Edgerton, Indiana University - Victor Erlich, Yale University - Merle Fainsod, Harvard University - Alexander Gerschenkron, Harvard University - Gregory Grossman, University of California - Chauncy D. Harris, University of Chicago - John N. Hazard, Columbia University - Alex Inkeles, Harvard University - Charles Jelavich, Indiana University - Anatole G. Mazour, Stanford University Philip E. Mosely, Columbia University - Oliver H. Radkey, University of Texas - Alfred Senn, University of Pennsylvania - Demitri B. Shimkin, University of Illinois - Gleb Struve, University of California - René Wellek, Yale University - Francis J. Whitfield, University of California

\section{EDITORIAL STAFF}

EDITOR

Donald W. Treadgold

University of Washington

ASSOCIATE EDITOR

Gladys Greenwood

ASSISTANT EDITOR

Leila Charbonneau

EDITORIAL ASSISTANT

Marilyn Waesche

The Editors assume no responsibility for statements of fact or opinion made by contributors.

The Slavic Review (formerly The American Slavic and East European Review) is published quarterly, in March, June, September, and December, by the American Association for the Advancement of Slavic Studies, Inc., and is sent to all Association members. Members also receive an annual American Bibliography of Russian and East European Studies and a semiannual Newsletter. Applications for membership are accepted by the Secretary of the Association, Professor Ralph T. Fisher, 1207 West Oregon Street, University of Illinois, Urbana, Illinois 61801, from individuals professionally engaged in the field. Nonmembers also may place subscriptions with Professor Fisher. Subscriptions, without membership, are $\$ 12.00$ a year, foreign and domestic postage included. Single numbers are \$3.25.

Articles submitted and books for review, as well as all correspondence concerning editorial matters, should be addressed to Slavic Review, Thomson Hall, University of Washington, Seattle, Washington 98105. All communications regarding membership or subscriptions and all changes of address should be sent to Professor Fisher in Urbana.

Items for the "News of the Profession" section should be addressed to Professor Frank Y. Gladney in care of the AAASS in Urbana.

Published for the American Association for the Advancement of Slavic Studies, Inc., at Mt. Royal and Guilford Avenues, Baltimore, Maryland 21202. Second-class postage paid at Baltimore, Maryland.

Copyright (C) 1969 by the American Association for the Advancement of Slavic Studies, Inc. 


\title{
SLAVIC REVIEW
}

AMERICAN QUARTERLY OF SOVIET AND EAST EUROPEAN STUDIES

Formerly: The American Slavic and East European Review

\author{
LOUISE E. LUKE \\ Columbia University \\ Managing Editor through October 1968
}

DONALD W. TREADGOLD

University of Washington

Editor from November 1, 1968

VOLUME XXVII • 1968

Copyright $\odot 1968,1969$ by the American Association

for the Advancement of Slavic Studies, Inc. 


\title{
CONTENTS OF VOLUME XXVII
}

\author{
Number 1, March 1968
}

\section{ARTICLES}

J. Luria (Ia. S. Lur'e) : Problems of Source Criticism (with Reference to Medieval Russian Documents) .................. 1

Fred E. Dohrs: Incentives in Communist Agriculture: The Hungarian

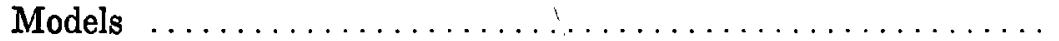

Anthony Cross: Problems of Form and Literary Influence in the Poetry of Karamzin

Allen Sinel: Educating the Russian Peasantry: The Elementary School Reforms of Count Dmitrii Tolstoi

Raymond Hutchings: The Weakening of Ideological Influences Upon Soviet Design

\section{NOTES AND COMMENTS}

Hugh Ragsdale: The Origins of Bonaparte's Russian Policy . . . . . . . 85

Francis B. Randall: Herzen's From the Other Shore . . . . . . . . . . 91

Bernard Choseed: Categorizing Soviet Yiddish Writers .......... 102

REVIEW ARTICLE

Ihor Sevčenko: New Cambridge History of the Byzantine Empire . . . 109 FORUM

Frank G. Siscoe: Eugene Schuyler, General Kaufman, and Central Asia ... . . . . . . . . . . . . . . . . . . . . . . . . . . . . . 119

David MacKenzie: Schuyler: Honorable But Misled ........... 124

REVIEWS $\ldots \ldots \ldots \ldots \ldots \ldots \ldots \ldots \ldots \ldots \ldots \ldots \ldots \ldots \ldots \ldots \ldots \ldots$

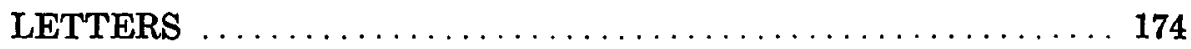

NEWS OF THE PROFESSION $\ldots \ldots \ldots \ldots \ldots \ldots \ldots \ldots \ldots \ldots \ldots \ldots$

BOOKS RECEIVED $\ldots \ldots \ldots \ldots \ldots \ldots \ldots \ldots \ldots \ldots \ldots \ldots$

\section{Number 2, June 1968}

\section{ARTICLES}

Michael Cherniavsky: Ivan the Terrible as Renaissance Prince . . . . . 195

Jan M. Michal: Czechoslovakia's Foreign Trade . . . . . . . . . . . . . 212

Frederic Lilge: Lenin and the Politics of Education . . . . . . . . . 230

Carl R. Proffer: From Otchaianie to Despair . . . . . . . . . . . 258

Keith Hitchins: The Russian Revolution and the Rumanian Socialist Movement, $1917-1918 \ldots \ldots \ldots \ldots \ldots \ldots \ldots \ldots \ldots \ldots \ldots$

NOTES AND COMMENTS

William M. Mandel: Arthur Ransome: Eyewitness in Russia 1919 . . . 290 
REVIEW ARTICLE

Robert C. Tucker: Svetlana Alliluyeva as Witness of Stalin

\section{FORUM}

R. M. Davison: Moral Ambiguity in Dostoevski . . . . . . . . . . . 313

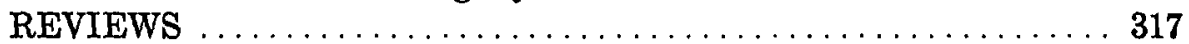

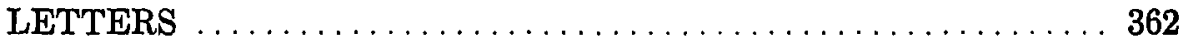

NEWS OF THE PROFESSION $\ldots \ldots \ldots \ldots \ldots \ldots \ldots \ldots \ldots \ldots, \ldots \ldots$

BOOKS RECEIVED $\ldots \ldots \ldots \ldots \ldots \ldots \ldots \ldots \ldots \ldots \ldots \ldots$

Number 3, September 1968

\section{ARTICLES}

J. William Leasure and Robert A. Lewis: Internal Migration in Russia in the Late Nineteenth Century .................... 375

Robert J. Osborn: Crime and the Environment: The New Soviet Debate .................................. 395

Yaroslav Bilinsky: Education of the Non-Russian Peoples in the USSR, 1917-1967: An Essay

NOTES AND COMMENTS

Marin Pundeff: The University of Sofia at Eighty

REVIEW ARTICLES

Wiktor Weintraub: Three Volumes of the Nowy Korbut

Simon Karlinsky: Igor Stravinskii-East and West ...

\section{TRANSLATION}

William E. Harkins: A. K. Tolstoi's Parody History of the Russian State

FORUM

Paul Craig Roberts and Matthew A. Stephenson: Alienation and Central Planning in Marx ........................... 470

Howard J. Sherman: Alienation and Socialism in Marx ......... 475

Roberts and Stephenson: Reply: The Oneness of Socialism and Central Planning in Marx

\section{DOCUMENT}

George F. Kennan: Excerpts from a Draft Letter Written at Some Time During the First Months of $1945 \ldots \ldots \ldots \ldots \ldots \ldots \ldots \ldots .481$

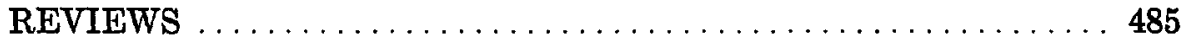

LETTERS . . . . . . . . . . . . . . . . . . . . . . . . . . . . 506

NEWS OF THE PROFESSION $\ldots \ldots \ldots \ldots \ldots \ldots \ldots \ldots \ldots \ldots$

BOOKS RECEIVED ........................... 520 


\section{Number 4, December 1968}

\section{ARTICLES}

John P. Sontag: Tsarist Debts and Tsarist Foreign Policy

Alan W. Fisher: Enlightened Despotism and Islam Under Catherine II

J. G. Garrard: Narrative Technique in Chulkov's Prigozhaia povari$k h a$

Alexander J. Groth: The Legacy of Three Crises: Parliament and Ethnic Issues in Prewar Poland ........................... 564

Robert C. Williams: "Changing Landmarks" in Russian Berlin, 19221924

NOTES AND COMMENTS

H. W. Dewey: Old Muscovite Concepts of Injured Honor (Beschestie) ................................... 594

Nathan Smith: The Role of Russian Freemasonry in the February Revolution: Another Scrap of Evidence ................. 604

Alex M. Shane: Russian Literary Periodicals (1901-1916) at the Helsinki University Library . . . . . . . . . . . . . . . . 609

Karl von Loewe: The Manuscript Section at the Lithuanian Academy of Sciences ...............................615

Roger Beasley: Bibliographies on Czech Literature and Language . . . 618

REVIEW ARTICLE

Nathan Rosen: Dostoevsky's Notebooks ..................625

\section{TRANSLATION}

Bertram D. Wolfe, translator: Two Poems . . . . . . . . . . . . 636

REVIEWS ................................ 638

DOCTORAL DISSERTATIONS, 1967-1968 (Compiled by Jesse J.

Dossick) ......................................... 694

NEWS OF THE PROFESSION $\ldots \ldots \ldots \ldots \ldots \ldots \ldots \ldots \ldots \ldots \ldots$

BOOKS RECEIVED ............................. 711

INDEX TO VOLUME XXVII (1968) $\ldots \ldots \ldots \ldots \ldots \ldots \ldots \ldots, 715$ 